\title{
Pola sebaran kelompok telur Ostrinia furnacalis Guenée (Lepidoptera: Crambidae) pada lahan jagung
}

\author{
Distribution pattern of Ostrinia furnacalis Guenée \\ (Lepidoptera: Crambidae) egg-mass on maize-field \\ Yosefus F. da-Lopez ${ }^{*}$, Y. Andi Trisyono ${ }^{2}$, Witjaksono² ${ }^{2}$ Subiadi $^{3}$ \\ ${ }^{1}$ Jurusan Manajemen Pertanian Lahan Kering Politeknik Pertanian Negeri Kupang \\ Jalan Adisucipto Penfui PO. Box 1152, Kupang Nusa Tenggara Timur 85011 \\ ${ }^{2}$ Jurusan Hama dan Penyakit Tumbuhan, Fakultas Pertanian, Universitas Gadjah Mada \\ Jalan Flora No.1 Bulaksumur, Yogyakarta 55281 \\ ${ }^{3}$ Balai Pengkajian Teknologi Pertanian Papua Barat \\ Jalan Base-camp Perkantoran Pemprov Papua Barat Arfai Gunung Manokwari
}

(diterima September 2012, disetujui April 2013)

\begin{abstract}
ABSTRAK
Penggerek jagung Asia, Ostrinia furnacalis Guenée, dikenal sebagai hama penting tanaman jagung baik pada fase vegetatif maupun fase generatif. Pada fase generatif, pengambilan keputusan pengelolaan $O$. furnacalis perlu didasarkan pada kepadatan kelompok telur sebelum telur hama menetas dan tanaman mengalami kerusakan. Studi penyebaran kelompok telur O. furnacalis dilakukan pada tanaman jagung di Kebun Pendidikan, Penelitian, dan Pengembangan Pertanian (KP4) UGM, Yogyakarta. Tujuan penelitian adalah mengetahui sebaran horizontal dan vertikal kelompok telur O. furnacalis pada tanaman jagung fase generatif dan pola sebarannya, baik horizontal maupun vertikal. Pengamatan dilakukan terhadap jumlah kelompok telur pada setiap tanaman sampel, berdasarkan sebaran vertikal/horizontal. Pola sebaran dianalisis menggunakan rasio ragam terhadap rata-rata $\left(\sigma 2 / \mu=I_{\delta}\right)$, indeks Morisita $\left(I_{\gamma}\right)$, dan parameter binomial negatif (nilai- $\mathrm{K}$ ). Hasil pengamatan menunjukkan bahwa pola sebaran kelompok telur $O$. furnacalis baik horizontal maupun vertikal adalah mengelompok $(\sigma 2>\mu$ atau $\sigma 2 / \mu>1)$. Sejalan dengan bertambahnya umur tanaman, derajat pengelompokkan tersebut cenderung menurun (nilai-к meningkat; nilai indeks Morisita menurun) dan ada kemungkinan bergerak menuju acak (sebaran Poison) bergantung pada heterogenitas lingkungan, seperti iklim mikro, ketersediaan makanan berupa tanaman atau bagian tanaman yang disukai, dan musuh alami. Hasil penelitian ini menyimpulkan bahwa pola sebaran horizontal maupun vertikal kelompok telur $O$. furnacalis pada tanaman jagung fase generatif adalah mengelompok dengan derajat pengelompokkan yang cenderung menurun dengan bertambahnya umur tanaman jagung. Informasi tentang penyebaran kelompok telur $O$. furnacalis dapat digunakan untuk menjelaskan biologi dan ekologi serangga dan pengembangan strategi manajemen hama yang efektif.
\end{abstract}

Kata kunci: Ostrinia furnacalis, sebaran kelompok telur, indeks dispersi

\begin{abstract}
Asian corn borer, Ostrinia furnacalis Guenée, is known as an important pest of maize, Zea mays L., in both whorl and reproductive stages. Management decisions based on egg-mass density is useful because decision is made before damage occurs. Observation on $O$. furnacalis egg-mass distribution in maize-field was carried out in Agricultural Training, Research, and Development Station (ATRD) UGM, Yogyakarta. The number of egg-masses laid on each plant surface in maize-field was sampled
\end{abstract}

\footnotetext{
*Penulis korespondensi: Yosefus F. da-Lopez. Politeknik Pertanian Negeri Kupang

Jalan Adisucipto Penfui, PO. Box 1152, Kupang-Nusa Tenggara Timur 85011

Tel: 08113828676,Email: yosdapisco@gmail.com
} 
in reproductive stage of corn at $52-58$ days after planting. The spatial dispersion was analyzed using the ratio variance-to-mean $\left(\sigma 2 / \mu=\mathrm{I}_{\delta}\right)$, Morista's Index $\left(\mathrm{I}_{\gamma}\right)$, and the negative binomial parameter ( $\kappa$-value). The results showed that horizontal and vertical distributions were aggregated distributions $(\sigma 2>\mu$ or $\sigma 2 / \mu>1)$. In line with the increasing age of plant, the degree of clustering or aggregation likely tended to decline (the $\kappa$-value increased, Morisita index decreased) indicating the possible departure from aggregation to randomness (Poison distribution) due to the heterogeneity of the environment, such as microclimate, preferred parts of the plants, and occurrence of natural enemies. The results concluded that the horizontal and vertical distributions of egg-masses of $O$. furnacalis on corn in generative phase were clustered with the degree of clustering tended to decrease by the increase of age of corn. These findings provide the bases for further study on the ecology and biology of $O$. furnacalis for management decision-making process.

Key words: Ostrinia furnacalis, egg-mass distribution, dispersion index

\section{PENDAHULUAN}

Penggerek batang jagung (Ostrinia furnacalis Guenée) dikenal sebagai serangga hama penting pada tanaman jagung di wilayah Asia, termasuk Indonesia. Kerusakan tanaman jagung yang diakibatkan oleh hama ini dapat mencapai $98 \%$ (Abdullah \& Rauf 2011). Pada fase whorl (fase vegetatif atau fase daun menggulung), kerusakan pada daun mencapai $75-91 \%$ sementara kerusakan tassel (bunga jantan) dalam fase tasseling (pembentukan bunga jantan) mencapai 24,5-96,5\% dan kerusakan tongkol dan batang di atas $85 \%$ (Dunsong et al. 2004). Kehilangan hasil jagung akibat serangan hama ini tergolong tinggi, yaitu sekitar 18-80\% (Nonci et al. 1996; Ceballo \& Rejesus 1983) sehingga hama ini perlu dikelola secara efektif berdasarkan hasil pemantauan menggunakan prosedur sampling yang tepat.

Adanya perbedaan biologi $O$. furnacalis pada jagung fase vegetatif dan fase reproduktif, yaitu silking (pembentukan bunga betina) dan tasselling, menyebabkan prosedur sampling dan ambang kerusakan ekonomi pada kedua generasi tersebut juga berbeda (Wright et al. 2002). Pada fase vegetatif, keputusan pengelolaan didasarkan pada frekuensi kerusakan tanaman dan jumlah larva hidup per tanaman rusak, sedangkan pada jagung fase generatif atau reproduktif, keputusan pengelolaan hama ini didasarkan pada kepadatan kelompok telur (Wright et al. 2002). Dengan demikian, sebelum keputusan pengelolaan hama diambil, pemahaman tentang penyebaran kelompok telur $O$. furnacalis dan pola sebarannya penting untuk menjelaskan biologi dan ekologi hama dan juga penting dalam menentukan ukuran contoh yang optimal sebelum keputusan sampling 82 diambil dan pengembangan strategi manajemen hama yang efektif. Informasi mengenai perilaku penyebaran hama ini juga diperlukan dalam pengembangan model yang dapat digunakan untuk meramalkan potensi evolusi resistensi hama ini terhadap tanaman jagung transgenik (Qureshi et al. 2005).

Pola sebaran merupakan salah satu karakteristik ekologis yang paling penting dari suatu spesies dan bermanfaat untuk kepentingan praktis dan teoritis (Southwood \& Henderson 2000). Perubahan temporal dalam dispersi akan selalu terjadi dan perbedaan pola dispersi dapat berbeda dalam setiap tahap perkembangan dari suatu spesies (Elliot 1977). Berdasarkan hubungan antara ragam dan rata-rata $\left(\sigma^{2} / \mu\right)$, pola sebaran hama dapat dikategorikan menjadi teratur, acak, dan mengelompok. Ketiga jenis pola sebaran tersebut dapat diamati pada $O$. furnacalis dan sebagian besar pola sebaran ini disebabkan oleh perilaku serangga yang berhubungan dengan perubahan lingkungan (Elliot 1977; Southwood \& Henderson 2000).

Sebaran acak mengikuti sebaran Poison dengan ragam sama dengan rata-rata $\left(\sigma^{2}=\mu\right)$ (Elliot 1977). Pada pola sebaran ini, setiap individu memiliki kesempatan yang sama untuk menempati setiap titik dalam suatu wilayah sehingga kehadiran suatu individu tidak memengaruhi individu lain di dekatnya (Elliot 1977; Southwood \& Henderson 2000). Dengan demikian, jika serangga memilih tanaman atau bagian tertentu tanaman secara acak untuk bertelur, penyebaran kelompok telur dipastikan mengikuti sebaran Poison.

Jika ragam lebih kecil dari rata-rata $\left(\sigma^{2}<\mu\right)$ maka pola sebaran mengikuti sebaran binomial positif dan disebut pola sebaran teratur (Elliot 
1977). Pada pola sebaran ini, individu dalam suatu populasi relatif berjejalan dan bergerak saling menjauhi satu sama lain (Elliot 1977; Southwood \& Henderson 2000) sehingga jika serangga menghindari tumbuhan tempat dimana kelompok telur akan diletakkan maka pola sebaran yang ada pasti teratur.

Pola sebaran mengelompok mengikuti distribusi binomial negatif, dengan ragam lebih besar dari rata-rata $\left(\sigma^{2}>\mu\right)$ (Elliot 1977). Pada pola sebaran ini, individu tertarik dan bergerombol pada titik tertentu dengan atau tanpa pengaruh lingkungan. Pengelompokkan dapat berbeda dalam habitat yang sama dan mungkin bervariasi dalam suatu area yang kecil (Elliot 1977). Dengan demikian, jika serangga memiliki preferensi yang jelas terhadap tanaman atau bagian tertentu tanaman di lapangan, pola sebaran yang mengelompok pasti ditemukan. Kepadatan kelompok telur yang lebih tinggi dapat mengindikasikan adanya pola sebaran teratur atau mengelompok dan kepadatan kelompok telur yang rendah dapat mengindikasikan pola sebaran acak atau bahkan sulit dideteksi pola sebaran (Elliot 1977). Akan tetapi, pada umumnya penyebaran kelompok telur di lapangan tidak selalu benarbenar acak, mengelompok atapun teratur (Elliot 1977; Southwood \& Henderson 2000).

Selain indeks dispersi $\left(\mathrm{I}_{\delta}\right)$, yaitu rasio ragam terhadap rata-rata $\left(\sigma^{2} / \mu\right)$, pola sebaran populasi juga dapat ditentukan menggunakan nilai- $\kappa$ Binomial negatif dan indeks Morisita $\left(\mathrm{I}_{\gamma}\right)$ (Elliot 1977; Southwood \& Henderson 2000; Rosenberg \& Anderson 2011). Rasio ragam terhadap ratarata $\left(\sigma^{2} / \mu\right)$ terdistribusi menurut sebaran Chisquare $(\chi 2)$ dengan n-1 derajat bebas (Elliot 1977; Southwood \& Henderson 2000; Rosenberg \& Anderson 2011). Nilai ini umumnya bermanfaat untuk menjelaskan dispersi spasial serangga yang sesuai dengan sebaran Poison (acak), tetapi tidak dapat menjelaskan derajat pengelompokkan populasi (Elliot 1977). Suatu indeks tunggal tidak cukup menyajikan dengan baik pola sebaran menuju acak atau mengelompok (Kuno 1991) sehingga nilai- $\kappa$ Binomial negatif dan nilai indeks Morisita $\left(\mathrm{I}_{\gamma}\right)$ dapat digunakan untuk mengkonfirmasi nilai rasio ragam terhadap ratarata (Khaing et al. 2002).
Fase generatif jagung merupakan fase disukai betina $O$. furnacalis untuk meletakkan telur karena ketersediaan makanan berupa bunga jantan dan bunga betina bagi larva $O$. furnacalis yang baru menetas sekaligus sebagai tempat persembunyian larva tersebut dan tidak adanya kandungan DIMBOA pada tanaman jagung. Penyebaran kelompok telur pada fase ini dapat terjadi secara horizontal maupun vertikal. Penyebaran horizontal, yaitu penyebaran yang terjadi antar strata lahan dan strata tanaman, sedangkan penyebaran vertikal, yaitu penyebaran dalam strata daun pada tanaman. Penelitian ini bertujuan untuk mengetahui penyebaran horizontal dan vertikal kelompok telur O. furnacalis pada tanaman jagung fase generatif dan pola penyebarannya baik horizontal maupun vertikal.

\section{BAHAN DAN METODE}

Pengamatan terhadap penyebaran kelompok telur O. furnacalis dilakukan pada lahan jagung fase generatif di Kebun Pendidikan, Penelitian, dan Pengembangan Pertanian (KP4) Universitas Gadjah Mada, Yogyakarta.

Pertanaman. Kondisi pertanaman yang diamati terinfestasi $O$. furnacalis secara alami dengan jumlah kelompok telur yang tinggi. Tempat pengamatan merupakan kebun percobaan yang disusun dalam rancangan petak terpisah (RPT) dengan rancangan lingkungan rancangan acak kelompok (RAK). Luas lahan adalah $48 \mathrm{~m} \times$ $14 \mathrm{~m}$, varietas jagung ditanam adalah jagung hibrida pioneer (P-21) dengan jarak tanam $80 \mathrm{~cm} \times 20 \mathrm{~cm}$. Tanaman dipupuk dan disemprot insektisida pada awal tanaman muda. Pemupukan menggunakan Urea $300 \mathrm{~kg} / \mathrm{ha}$, TSP $100 \mathrm{~kg} / \mathrm{ha}$, dan KCl $75 \mathrm{~kg} / \mathrm{ha}$. Penyemprotan menggunakan insektisida berbahan aktif imidakloprid untuk mengatasi serangan hama pemakan daun (Curcullionidae) pada saat tanaman berumur 10-14 hari setelah tanam.

Penetapan contoh. Pengamatan penyebaran kelompok telur $O$. furnacalis menggunakan metode stratifikasi, yaitu stratifikasi terhadap lahan, tanaman, dan daun. Stratifikasi terhadap 
lahan dan tanaman dilakukan untuk menentukan sebaran horizontal, sedangkan stratifikasi terhadap daun digunakan untuk menentukan sebaran vertikal. Stratifikasi lahan dengan menetapkan tiga petak contoh sepanjang satu garis diagonal kebun. Setiap petak contoh berukuran 3,2 $\mathrm{m} \times 2,6 \mathrm{~m}$ dengan karakteristik masing-masing. Petak contoh I (strata pinggir-dalam) berbatasan langsung dengan lahan tanaman lain, sumber irigasi, dan area yang ditumbuhi gulma. Petak contoh II (strata tengah) berada di tengah-tengah kebun jagung. Petak contoh III (strata pinggir-luar) berbatasan langsung dengan lahan kosong yang sedang lahan dalam pengolahan dan jalan raya. Tanaman dalam setiap petak contoh distratifikasi menjadi tanaman-pinggir, tanaman-antara, dan tanamantengah (Gambar 1). Daun pada setiap tanaman contoh distratifikasi menjadi tiga bagian, yaitu daun bawah, daun tengah, dan daun atas; masingmasing sepertiga dari total daun (13-16 daun) per tanaman. Setiap petak contoh terdapat 70 tanaman jagung. Jumlah kelompok telur dihitung pada setiap daun per tanaman dalam setiap petak contoh (strata lahan). Penyebaran kelompok telur dalam lahan (sebaran horizontal) ditentukan dengan menghitung jumlah kelompok telur yang diletakkan pada 210 tanaman yang berada dalam tiga strata lahan atau tiga petak contoh dengan jumlah tanaman dalam setiap strata lahan sebanyak 70 tanaman. Selanjutnya, tanaman yang ada dalam setiap strata lahan dikelompokkan menjadi tiga strata, yaitu pinggir, antara, dan tengah (Gambar 1). Di setiap strata, jumlah kelompok telur dihitung, yaitu 36 tanaman pada strata pinggir, 24 tanaman pada strata antara, dan 10 tanaman pada strata tengah. Sebaran vertikal atau sebaran kelompok telur pada daun ditentukan dengan menghitung jumlah kelompok telur yang ditemukan pada setiap strata daun yang ditetapkan, yaitu daun bawah, daun tengah, dan daun atas. Data jumlah kelompok telur dalam strata lahan, strata tanaman, dan strata daun, digunakan untuk menjelaskan pola sebaran horisontal dan pola sebaran vertikal kelompok telur O. furnacalis.

Metode pengamatan. Pengamatan penyebaran kelompok telur $O$. furnacalis dilakukan dengan menghitung jumlah kelompok pada tanaman jagung berumur 52, 55, dan 58 hari setelah tanam (HST) dengan frekuensi pengamatan 3 hari sekali. Data jumlah kelompok telur pada 52 HST digunakan sebagai data awal, selanjutnya, jumlah kelompok telur dihitung secara kumulatif sampai dengan 58 HST. Perubahan jumlah kelompok telur pada setiap HST dihitung untuk mengetahui apakah terjadi peningkatan atau penurunan dalam peletakkan telur. Dalam pengambilan data awal (pada 52 HST), setiap kelompok telur baik yang baru maupun yang lama atau terparasit dihitung. Kelompok telur yang telah dihitung, dihilangkan dari daun untuk mencegah kesalahan atau pengulangan pengambilan data yang sama dalam pengambilan data berikutnya. Penentuan frekuensi pengamatan 3 hari sekali didasarkan pertimbangan efisiensi waktu dan bahwa telur O. furnacalis siap untuk menetas setelah tiga hari peletakkan telur.

Analisis data. Data jumlah kelompok telur (data kumulatif) yang ditemukan dalam setiap strata lahan, tanaman, dan daun ditentukan persentasenya dan dianalisis secara deskriptif. Pola sebaran ditentukan melalui nilai indeks dispersi $\left(\mathrm{I}_{\delta}\right)$, yaitu ratio ragam terhadap rata-rata dan dikonfirmasi melalui nilai- $\kappa$ Binomial negatif dan indeks Morisita $\left(\mathrm{I} \gamma_{\mathrm{g}}\right.$ ) (Elliot 1977; Southwood \& Henderson 2000; Rosenberg \& Anderson 2011).

\begin{tabular}{|l|l|l|l|l|l|l|l|l|l|l|l|l|l|}
\hline 57 & 58 & 59 & 60 & 61 & 62 & 63 & 64 & 65 & 66 & 67 & 68 & 69 & 70 \\
\hline 56 & 55 & 54 & 53 & 52 & 51 & 50 & 49 & 48 & 47 & 46 & 45 & 44 & 43 \\
\hline 29 & 30 & 31 & 32 & 33 & 34 & 35 & 36 & 37 & 38 & 39 & 40 & 41 & 42 \\
\hline 28 & 27 & 26 & 25 & 24 & 23 & 22 & 21 & 20 & 19 & 18 & 17 & 16 & 15 \\
\hline 1 & 2 & 3 & 4 & 5 & 6 & 7 & 8 & 9 & 10 & 11 & 12 & 13 & 14 \\
\hline
\end{tabular}

Gambar 1. Stratifikasi tanaman dalam petak sampel. $\square$ : tanaman pinggir (34 tanaman); $\square$ : tanaman antara (26 tanaman); $\square$ : tanaman tengah (10 tanaman). 
Perbedaan penyebaran kelompok telur antar strata dan kesesuaian nilai indeks diuji menggunakan Pearson Chi-Square test $(\alpha=0,05 ; \mathrm{db})$ (Elliot 1977; Southwood \& Henderson 2000; Rosenberg \& Anderson 2011). Penentuan nilai indeks dispersi dan ukuran contoh efektif dalam strata lahan menggunakan perangkat lunak PASSaGE Version 2 (Rosenberg \& Anderson 2011).

\section{HASIL}

\section{Sebaran horizontal kelompok telur O.furnacalis}

Secara umum, hasil pengamatan jumlah kelompok telur dalam setiap strata pengamatan disajikan pada Tabel 1. Jumlah kelompok telur pada strata pinggir-dalam lahan jagung lebih tinggi $( \pm 46 \%)$ daripada strata tengah $( \pm 40 \%)$ dan strata pinggir-luar $( \pm 14 \%)(\chi 2=202,00 ; \mathrm{db}=4$; $\mathrm{P}=0,000$; uji dua sisi) dan oviposisi cenderung menurun terutama dalam strata tengah $( \pm 0,3 \%)$ dan pinggir-luar $( \pm 1,1 \%)$ setelah tanaman berumur 55 hari setelah tanam (Gambar 2). Letak tanaman dalam setiap strata lahan juga memberikan sebaran kelompok telur yang berbeda $(\chi 2=200,00 ; d b=4$; $\mathrm{P}=0,000$; uji dua sisi) (Gambar 3). Oviposisi pada tanaman-tanaman pinggir atau terluar cenderung menurun, sedangkan oviposisi pada tanaman yang letaknya lebih ke tengah (bagian dalam) meningkat, terutama pada tanaman-tanaman yang ada dalam strata pinggir (Gambar 3). Jumlah kelompok telur yang ditemukan adalah 182, 230, 295 pada setiap

Tabel 1. Jumlah kelompok telur pada tanaman jagung dalam setiap strata pengamatan selama fase generatif

\begin{tabular}{|c|c|c|c|c|c|c|c|c|c|c|c|c|}
\hline \multirow{2}{*}{$\begin{array}{l}\text { Jumlah kelompok } \\
\text { telur }\end{array}$} & \multicolumn{4}{|c|}{52 HST } & \multicolumn{4}{|c|}{55 HST } & \multicolumn{4}{|c|}{58 HST } \\
\hline & A & B & $\mathrm{C}$ & Total & A & B & $\mathrm{C}$ & Total & A & B & $\mathrm{C}$ & Total \\
\hline Strata lahan & 242 & 205 & 81 & 528 & 258 & 228 & 84 & 570 & 295 & 251 & 86 & 632 \\
\hline \multicolumn{13}{|l|}{ Strata tanaman } \\
\hline - Pinggir & 89 & 57 & 43 & 189 & 95 & 68 & 44 & 207 & 108 & 44 & 45 & 197 \\
\hline - Antara & 114 & 94 & 26 & 234 & 122 & 101 & 27 & 250 & 137 & 27 & 27 & 191 \\
\hline - Tengah & 39 & 54 & 12 & 105 & 41 & 59 & 13 & 113 & 50 & 13 & 14 & 77 \\
\hline Total & 242 & 205 & 81 & 528 & 258 & 228 & 84 & 570 & 295 & 84 & 86 & 465 \\
\hline \multicolumn{13}{|l|}{ Strata daun } \\
\hline - Bawah & 90 & 87 & 44 & 221 & 90 & 93 & 45 & 228 & 90 & 94 & 45 & 229 \\
\hline - Tengah & 126 & 105 & 32 & 263 & 141 & 122 & 34 & 297 & 168 & 142 & 36 & 346 \\
\hline - Atas & 26 & 13 & 5 & 44 & 27 & 13 & 5 & 45 & 37 & 15 & 5 & 57 \\
\hline Total & 242 & 205 & 81 & 528 & 258 & 228 & 84 & 570 & 295 & 251 & 86 & 632 \\
\hline
\end{tabular}

A, B, dan C adalah strata lahan. A: pinggir-dalam; B: tengah lahan; C: pinggir-luar; HST: hari setelah tanam.

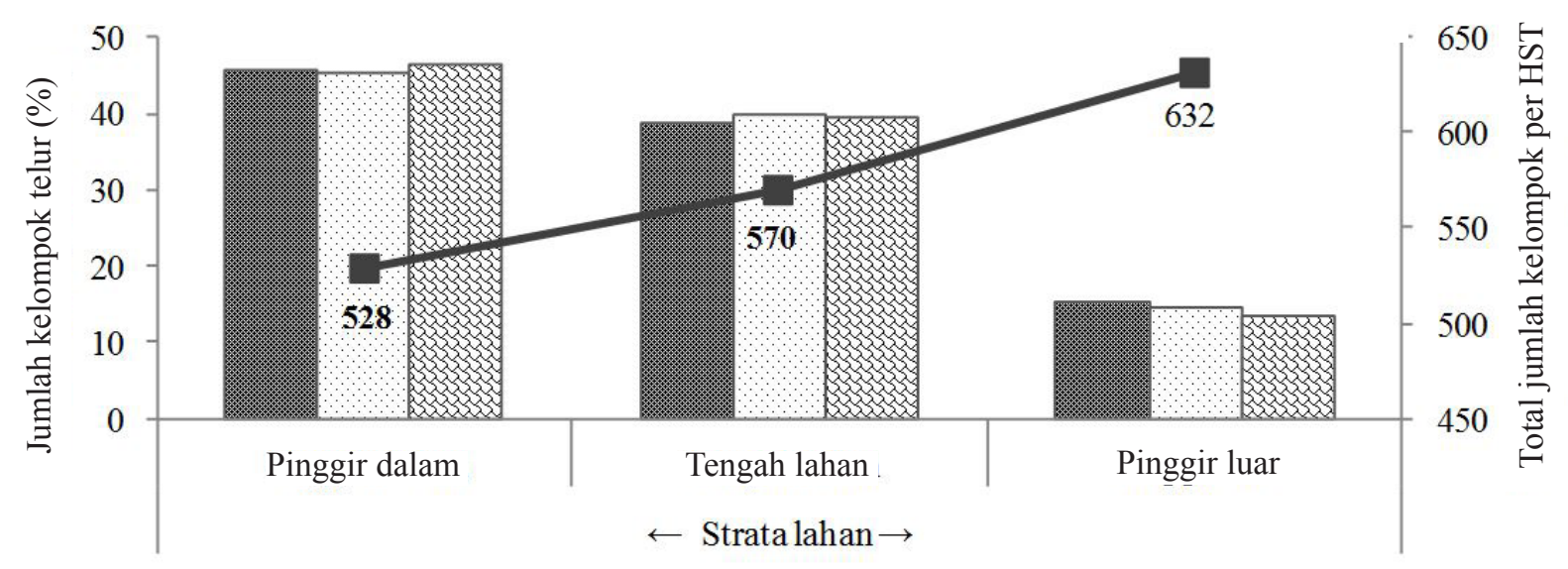

Gambar 2. Jumlah kelompok telur (\%) Ostrinia furnacalis dalam strata lahan tanaman jagung. Pinggir-dalam berbatasan langsung dengan area yang ditumbuhi banyak gulma, lahan tanaman lain dan sumber irigasi; pinggir-luar berbatasan langsung dengan lahan kosong dengan gulma yang jarang, jalan raya, dan tanpa sumber irigasi di dekatnya. ․․․․․ 52 hari setelah tanam (HST); $5: 55$ HST; : 58 HST; $\longrightarrow$ : total kelompok telur per HST. 
strata tanaman dalam strata pinggir luar; 146 , 188, 252 pada setiap strata tanaman dalam strata tengah; dan $51,69,86$ pada setiap strata tanaman dalam strata pinggir luar pada 52, 55, dan 58 hari setelah tanam.

\section{Sebaran vertikal kelompok telur O. furnacalis}

Penyebaran kelompok telur lebih banyak terjadi pada daun-daun tengah $( \pm 54,7 \%)$ daripada daun-daun bawah $(36,2 \%)$ dan daun-daun atas $(9,0 \%)(\chi 2=200,00 ; \mathrm{db}=4 ; \mathrm{P}=0,000 ;$ uji dua sisi) (Gambar 4). Jika dilihat per strata lahan, sebaran kelompok telur pada strata pinggir luar lebih banyak terjadi pada daun-daun bawah ( \pm $52,3 \%$ dari 86 kelompok telur) dibanding dengan dua strata lainnya (Gambar 4). Sejalan dengan bertambahnya umur tanaman jagung, oviposisi pada daun-daun bawah cenderung menurun $(5,62 \%)$ sementara oviposisi pada daun-daun tengah dan atas meningkat, masing-masing 4,94\% dan 0,69\% (Gambar 5).

\section{Pola sebaran horisontal kelompok telur $O$. furnacalis}

Pola sebaran kelompok telur dalam lahan jagung fase generatif adalah mengelompok $\left(\sigma^{2}\right.$ $>\mu$ atau nilai $\left.\mathrm{I}_{\delta}>1\right)$ serta memenuhi sebaran binomial negatif (nilai-א) dan dikonfirmasi oleh nilai indeks Morisita (I) (Gambar 6 dan 7). Pola pengelompokan bergerak atau semakin menguat

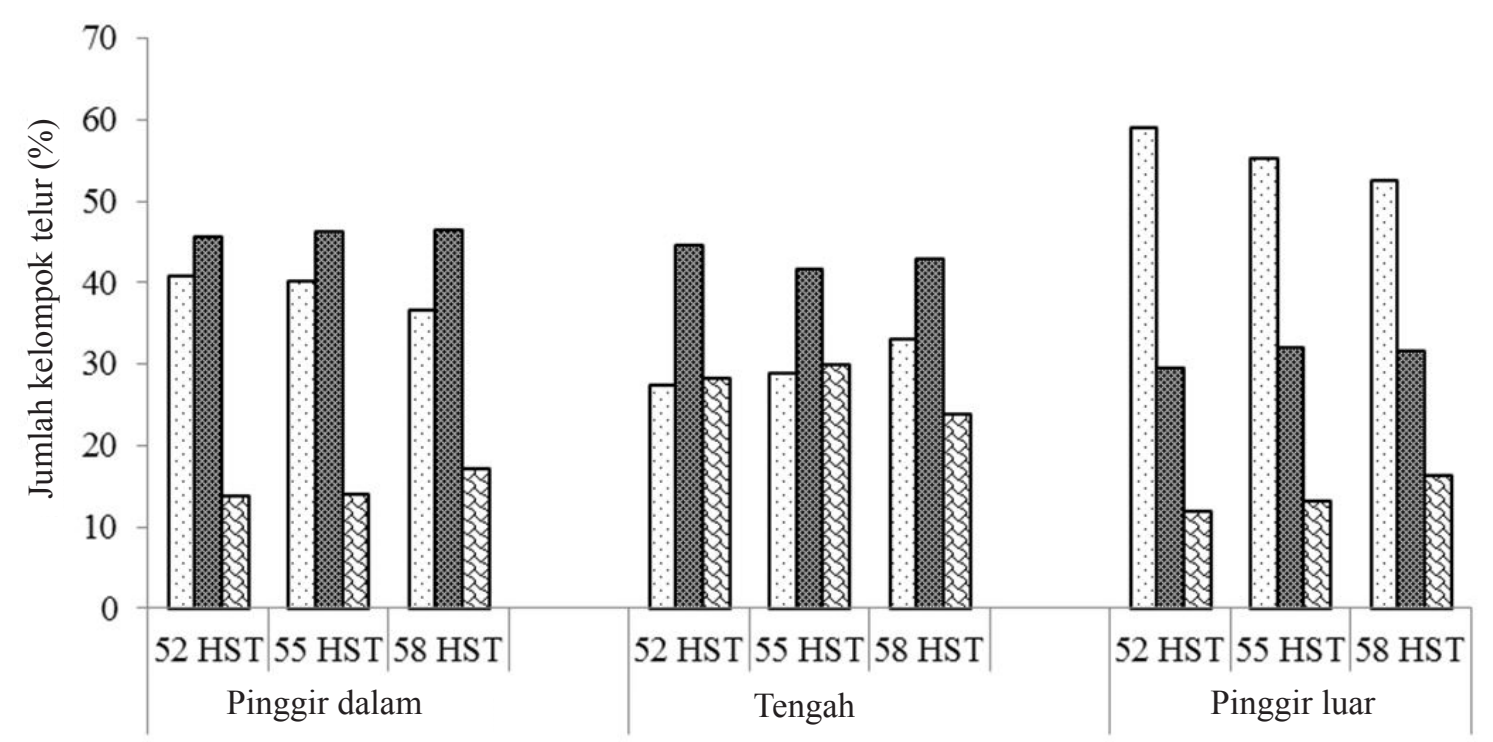

Gambar 3. Jumlah kelompok telur (\%) O. furnacalis pada strata tanaman dalam petak sampel (strata lahan) selama fase generatif. $\square$ : pingir; : antara; $\mathbf{\square}$ : tengah.



Gambar 4. Jumlah kumulatif kelompok telur Ostrinia furnacalis pada level daun tanaman jagung selama fase generatif. Diagram garis adalah jumlah kelompok telur per daun per strata lahan, sedangkan diagram batang adalah jumlah gabungan kelompok telur per daun dari ketiga strata lahan yang diamati. Angka persen adalah persentase jumlah kelompok telur per level/strata daun (bawah, atas, dan tengah) dari total jumlah 632 kelompok telur yang ditemukan selama pengamatan. $\square$ : gabungan; $\multimap$ : pinggir dalam; $\rightarrow-$ : tengah; $\multimap$ : pinggir luar. 




Gambar 5. Distribusi kelompok telur Ostrinia furnacalis pada level daun selama pengamatan dalam fase generatif. Diagram garis adalah persentase jumlah kelompok telur per level daun per umur tanaman dari total jumlah kelompok telur per umur tanaman (diagram batang). $\square$ : total; $\neg$ : daun bawah; $\rightarrow-$ : daun tengah; $\longrightarrow$ : daun atas.

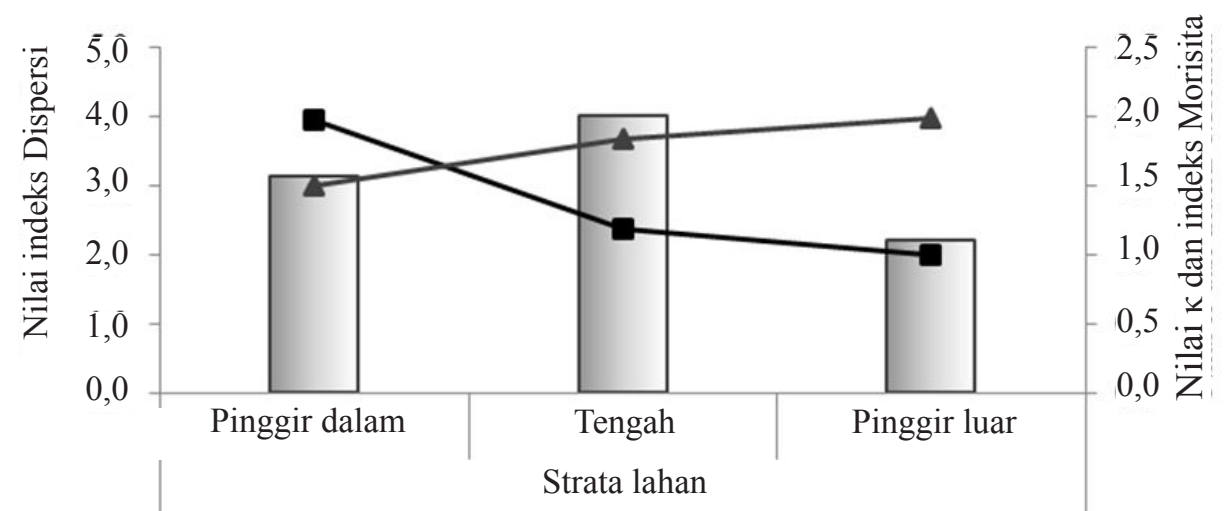

Gambar 6. Indeks dispersi kelompok telur Ostrinia furnacalis per strata lahan tanaman jagung fase generatif. Diagram batang adalah nilai $\mathrm{I}_{\delta}$ (indeks dispersi $=\sigma 2 / \mu$ ), sedangkan diagram garis adalah nilai $\kappa$ -Binomial negatif dan nilai $\mathrm{I}_{\gamma}$ (indeks Morisita). Nilai indeks dispersi dikonfirmasi melalui uji Chi-square $(\mathrm{p}=0,0000)$.

mengikuti hirarki sebagai berikut: strata pinggir dalam $\rightarrow$ strata tengah $\rightarrow$ strata pinggir luar (Gambar 6). Derajat pengelompokkan menurun dengan bertambahnya umur tanaman jagung (Gambar 7).

\section{Pola sebaran vertikal kelompok telur $O$.} furnacalis

Dalam strata daun (vertikal), pola sebaran kelompok telur adalah mengelompok $\left(\sigma^{2}>\mu\right.$ atau nilai $\left.I_{\delta}>1\right)$. Pola tersebut memenuhi dsebaran binomial negatif (nilai-א) dan dikonfirmasi oleh nilai indeks Morisita (I) (Gambar 8 dan 9). Pengelompokkan yang terjadi semakin menguat sesuai hirarki sebagai berikut: daun bawah $\rightarrow$ daun tengah $\rightarrow$ daun atas (Gambar 8) dengan derajat pengelompokkan yang cenderung menurun setelah tanaman memasuki umur 55 hari setelah tanam (Gambar 9).

\section{PEMBAHASAN}

Letak tanaman dalam lahan dapat berpengaruh terhadap penyebaran kelompok telur, jumlah kelompok telur dalam strata pinggir lahan dapat lebih tinggi daripada strata tengah (Lee 1988).

Perbedaan penyebaran kelompok telur (Gambar 2 dan 3) mungkin karena perbedaan perilaku betina yang berhubungan dengan kelembaban, ada atau tidak adanya action sites (gulma atau inang alternatif lainnya) bagi dewasa, praktek agronomi, iklim, dan interaksinya terhadap siklus hidupnya, dan faktor gangguan karena aktifitas manusia di sekitarnya.

Kelembaban relatif dan adanya embun atau air bebas sangat penting bagi betina dewasa untuk kawin dan oviposisi maupun untuk produksi telur dan kesuburan. Rata-rata kelembaban udara di lingkungan tanaman selama penelitian adalah 


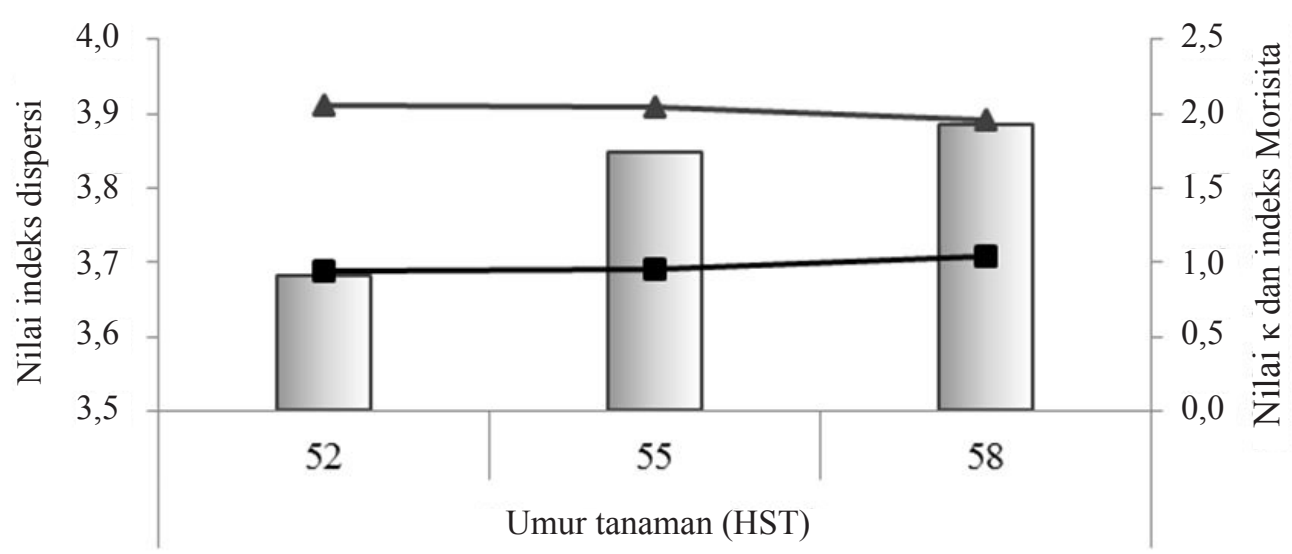

Gambar 7. Indeks dispersi distribusi kelompok telur Ostrinia furnacalis dalam strata lahan jagung selama pengamatan dalam fase generatif selama pengamatan. Diagram batang adalah nilai $\mathrm{I}_{\delta}$ (indeks dispersi $=\sigma 2 / \mu$ ), sedangkan diagram garis adalah nilai $\kappa$-Binomial negatif dan nilai $\mathrm{I}_{\gamma}$ (indeks Morisita). Nilai indeks dispersi dikonfirmasi melalui uji Chi-square $(\mathrm{p}=0,0000) . \square$ : indeks



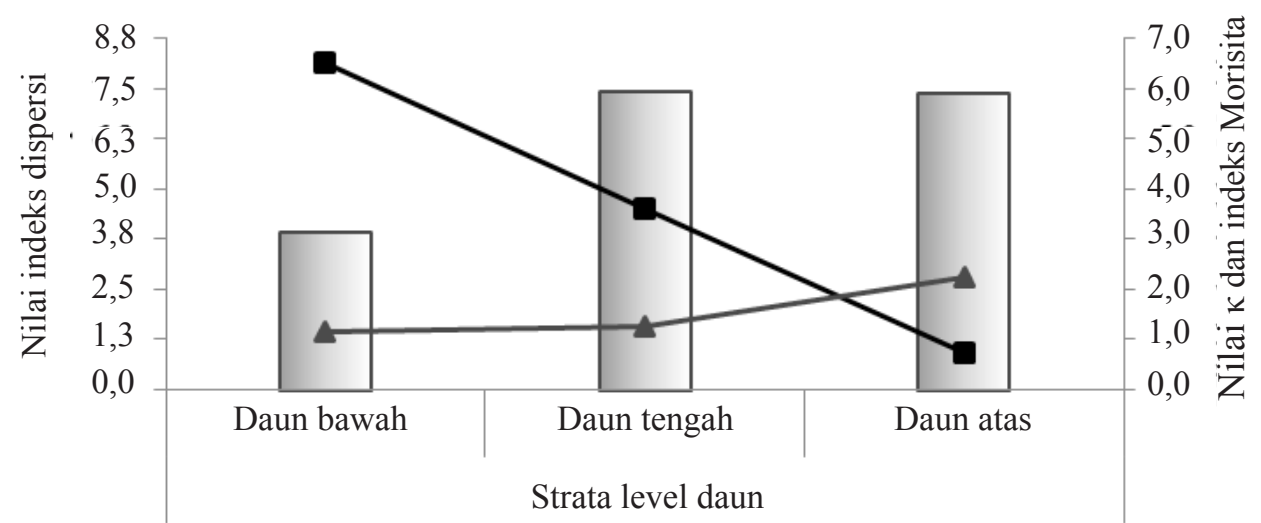

Gambar 8. Indeks dispersi distribusi kelompok telur Ostrinia furnacalis per strata daun tanaman jagung fase generatif. Diagram batang adalah nilai $I_{\delta}$ (indeks dispersi $=\sigma 2 / \mu$ ), sedangkan diagram garis adalah nilai $\kappa$-Binomial negatif dan nilai $\mathrm{I}_{\gamma}$ (indeks Morisita). Nilai indeks dispersi dikonfirmasi

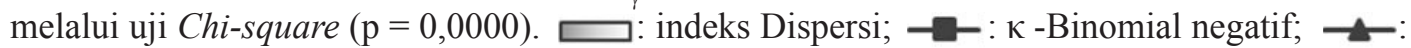
indeks Morisita.



Gambar 9. Indeksi dispersi distribusi kelompok telur Ostrinia furnacalis dalam strata daun selama pengamatan dalam fase generatif. Diagram batang adalah nilai $\mathrm{I}_{\delta}$ (indeks dispersi $=\sigma 2 / \mu$ ), sedangkan diagram garis adalah nilai $\kappa$-Binomial negatif dan nilai $\mathrm{I}_{\gamma}$ (indeks Morisita). Nilai indeks dipersi dikonfirmasi melalui uji Chi-square Nilai indeks dipersi dikonfirmasi melalui uji Chi-square $(\mathrm{p}=0,0000)$. 
Tabel 2. Modified t-Test for Correlation sebaran kelompok telur Ostrinia furnacalis pada strata lahan tanaman jagung

\begin{tabular}{lcccc}
\hline & & & \multicolumn{2}{c}{ CRH } \\
\cline { 4 - 5 } Variabel 1 & Variabel 2 & Korelasi & P (Kor.) terkoreksi & $\begin{array}{c}\text { Ukuran efektif } \\
\text { sampel }\end{array}$ \\
\hline Pinggir dalam & Tengah & 0,1342 & 0,9193 & 11,4062 \\
Pinggir dalam & Pinggir luar & 0,1428 & 0,6215 & 14,3278 \\
Tengah & Pinggir luar & 0,0339 & 0,5213 & 25,1414 \\
\hline
\end{tabular}

CHR: uji signifikansi korelasi menggunakan prosedur Clifford, Ricdardson, dan Hemon (CRH) (1989).

$74,11 \pm 6,48 \%$ dengan rata-rata suhu harian $28,93 \pm$ $0,91{ }^{\circ} \mathrm{C}$. Pengaruh kelembaban terhadap oviposisi betina tidak dianalisis secara khusus dalam penelitian ini, akan tetapi beberapa hasil penelitian lain menunjukkan bahwa lingkungan tanaman dengan kondisi kelembaban tinggi akan lebih suka dikunjungi oleh betina daripada lingkungan tanaman dengan kelembaban rendah (Qureshi et al. 2005; Hunt et al. 2011). Aktivitas betina akan terjadi lebih awal dan berlangsung lebih lama di daerah dengan kondisi kelembaban tinggi daripada daerah dengan kondisi kelembaban rendah (Hunt et al. 2011). Action sites atau daerah berumput merupakan tempat yang berada di dalam ataupun di luar lahan jagung atau $100 \mathrm{~m}$ dari lahan jagung terdekat, yang akan memberikan perlindungan atau tumpangan kepada dewasa karena memiliki iklim mikro yang lembab dan menguntungkan (karena kelembaban relatif yang tinggi) bagi dewasa untuk beristirahat dan kawin sebelum terbang ke ladang jagung untuk bertelur (Hunt et al. 2011). Jika dalam area yang sama terdapat tahap perkembangan jagung yang berbeda, betina lebih suka meletakkan telur pada area tanaman tempat fase tasselling, pollen shedding (pembentukan biji), dan tahap whorl berlangsung (Dunsong et al. 2004 \& 2007; Bas et al. 2008). Ekstrak pentana pada jagung fase tasselling dapat menstimulasi oviposisi; sementara telur, kotoran larva, dan tanaman atau bagian tertentu tanaman yang rusak memancarkan volatil yang dapat mengusir betinagravid untuk oviposisi pada lahan atau tanaman yang sudah ada kelompok telur atau larva (Bas et al. 2008). Ketertarikan betina untuk meletakkan telur pada daun juga disebabkan oleh lebih tingginya kadar glukosa di permukaan daun daripada batang (Derridj et al. 1992). Kebanyakan kelompok telur diletakkan pada daun-daun tengah $( \pm 54 \%$ dari
632 kelompok telur), seperti pada hasil penelitian ini (Gambar 4). Abdullah \& Rauf (2011) juga menemukan 54\% kelompok telur O. furnacalis pada daun ke-6 sampai daun ke-9, sementara Sorenson et al (1993) melaporkan 85\% kelompok telur diletakkan pada daun di sekitar tongkol primer. Meningkatnya oviposisi pada daun-daun tengah dan atas (Gambar 5) berhubungan dengan perkembangan tanaman yang telah memasuki fase generatif, yaitu pembentukan bunga betina dan pembentukan bunga jantan. Rambut tongkol dan bunga jantan akan menjadi habitat dan pakan bagi larva instar awal (Nafus \& Schreiner 1987). Pemilihan posisi daun sebagai tempat oviposisi tidak hanya karena ketersediaan makanan bagi larva instar awal, tetapi juga dipengaruhi oleh luas permukaan daun dan ketinggian tongkol (Spanglera \& Calvin 2001) serta faktor fisik, seperti suhu dan kelembaban (Chiang \& Hodson 1972; Despins \& Roberts 1986).

Kondisi lingkungan yang ada pada setiap strata lahan juga mempengaruhi betina dalam memilih level daun sebagai tempat oviposisi (Gambar 4). Strata lahan yang letaknya lebih terbuka (seperti dalam strata pinggir luar pada Gambar 4 dari hasil penelitian ini) dengan kondisi tanaman tidak selebat, seperti pada strata-strata lainnya menyebabkan betina lebih memilih daun-daun bawah untuk oviposisi sebagai adaptasi terhadap suhu dan kelembaban akibat penyinaran langsung matahari yang berlebihan. Pemilihan daun-daun bawah sebagai tempat yang lebih disukai untuk oviposisi juga dilaporkan oleh Despins \& Roberts (1986) pada untuk O. nubialis.

Pola sebaran hama mengikuti sebaran Poison (acak), sebaran binomial negatif (mengelompok), dan distribusi binomial positif(teratur)(Elliot 1977; Southwood \& Henderson 2000). Ketiga jenis pola 
sebaran tersebut dapat diamati pada $O$. furnacalis dan ditentukan melalui nilai indeks dispersi ( $\mathrm{I}_{\delta}$ atau ratio ragam terhadap rata-rata $\left(\sigma^{2} / \mu\right)$. Suatu indeks tunggal tidak cukup menyajikan dengan baik pola sebaran menuju acak atau mengelompok (Kuno 1991) sehingga nilai- $\kappa$ Binomial negatif dan nilai indeks Morisita $\left(\mathrm{I}_{\gamma}\right)$ digunakan untuk mengkonfirmasi nilai rasio ragam terhadap ratarata (Khaing et al 2002). Semakin besar nilai-א, derajat pengelompokkan semakin kecil atau sebaliknya (Southwood \& Henderson 2000); semakin kecil nilai indeks Morisita, semakin menurun derajat pengelompokkan suatu populasi atau sebaliknya (Rosenberg \& Anderson 2011).

Pada umumnya, distribusi kelompok telur di lapangan tidak selalu benar-benar acak, mengelompok atapun teratur (Elliot 1977; Southwood \& Henderson 2000). Gambar 6-9 dengan jelas menunjukkan bahwa ketika suatu area tidak lagi memiliki ruang yang cukup untuk oviposisi maka derajat pengelompokkan pada area tersebut akan menurun dan diikuti dengan meningkatnya derajat pengelompokkan pada area lain yang masih ada tempat yang memungkinkan untuk oviposisi. Dengan demikian, pola sebaran kelompok telur dapat berubah dari mengelompok menjadi teratur ataupun acak atau sebaliknya dari acak menjadi mengelompok dan teratur, bergantung pada kepadatan kelompok telur yang ada ataupun heterogenitas lingkungan. Kepadatan kelompok telur yang lebih tinggi dapat mengindikasikan adanya sebaran teratur atau mengelompok dan kepadatan kelompok telur yang rendah dapat mengindikasikan sebaran acak atau bahkan sulit dideteksi pola sebarannya (Elliot 1977).

Derajat dan arah pengelompokan yang terjadi dapat berbeda baik antar strata lahan dan daun maupun antar waktu (umur tanaman), bergantung pada kepadatan populasi dan ukuran maupun preferensi betina $O$. furnacalis terhadap tanaman/bagian tertentu tanaman untuk oviposisi dan faktor-faktor lainnya, seperti kelembaban, suhu, musuh alami, dan keadaan tanaman atau fase perkembangan tanaman, dan musuh alami (Nafus \& Schreiner 1987; Lee 1988; Southwood \& Henderson 2000; Dunsong et al. 2004; Qureshi et al. 2005; Dunsong et al. 2007; Bas et al. 2008; Hunt et al. 2011) sehingga penyebaran telur akan mengelompok hanya pada area-area tertentu yang 90 sesuai untuk oviposisi (Southwood \& Henderson, 2000). Kepadatan populasi yang telah tinggi pada strata tertentu dalam strata lahan (Gambar 2-3) dan strata daun (Gambar 4-5) akan mendorong betina untuk mengelompokkan telurnya pada strata lainnya yang kepadatan populasinya lebih rendah. Ini berarti bahwa derajat pengelompokkan telur pada strata sebelumnya akan menurun (menuju teratur atau acak) dan meningkat (semakin mengelompok) pada strata lainnya. Ketertarikan dan preferensi yang jelas dari serangga terhadap tanaman atau bagian tertentu tanaman di lapangan dan aktifnya agregasi akibat perilaku betina yang cenderung meletakkan kelompok telur secara berdekatan juga merupakan faktor penyebab terjadinya pola sebaran mengelompok (Elliot 1977; Southwood \& Henderson 2000). Menurunnya derajat pengelompokkan suatu populasi menunjukkan kemungkinan mengikuti sebaran Poison (menuju acak) akibat perubahan ukuran area yang digunakan oleh serangga atau menurunnya kepadatan populasi (Elliot 1977; Southwood \& Henderson 2000) sehingga kemungkinan individu untuk menempati setiap unit contoh menjadi rendah dan kontinyu sehingga pola sebarannya secara efektif menjadi acak (Southwood \& Henderson 2000).

Informasi tentang sebaran horizontal dan vertikal kelompok telur $O$. furnacalis dan pola sebarannya dapat digunakan untuk menyiapkan rencana sampling sekuensial. Sebaran kelompok telur $O$. furnacalis yang berbeda antar strata lahan menggambarkan bahwa stratifikasi lahan dalam pengambilan contoh dapat diterapkan untuk program pemantauan kelompok telur $O$. furnacalis pada lahan tanaman jagung fase generatif. Ukuran contoh efektif untuk setiap strata lahan adalah 1125 tanaman per $8,2 \mathrm{~m}^{2}$ atau sekitar 2-5 tanaman/ $\mathrm{m}^{2}$ (Tabel 2).

\section{KESIMPULAN}

Pola sebaran kelompok telur O. furnacalis pada tanaman jagung fase generatif horizontal maupun vertikal adalah mengelompok dengan derajat pengelompokkan yang cenderung menurun dengan bertambahnya umur tanaman jagung, yaitu menuju ke pola sebaran acak. Pergerakan pola 
sebaran menuju acak ini terjadi karena ketersediaan makanan yang semakin berkurang, yaitu umur atau fase tanaman jagung yang berhubungan dengan preferensi betina terhadap tanaman dan bagian tertentu tanaman yang menjadi makanan larva maupun, kondisi lingkungan yang sesuai bagi peletakkan telur oleh betina $O$. furnacalis.

\section{DAFTAR PUSTAKA}

Abdullah T, Rauf A. 2011. Karakteristik populasi dan serangan penggerek jagung Asia, Ostrinia furnacalis (Lepidoptera: Pyralidae) dan hubungannya dengan kehilangan hasil. Jurnal Fitomedika 7:175-181.

Bas PS, Dutton A, Bigler F, Van Lenteren JC. 2008. Oviposition behaviour and egg distribution of the European corn borer, Ostrinia nubilalis, on maize, and its effect on host finding by Trichogramma egg parasitoids. Bulletin of Insectology 61:303-312.

Ceballo FA, Rejesus BM. 1983. Tryptophan and lysine supplemented artificial diet for corn borer (Ostrinia furnacalis Guenee). Philippine Entomologist 6:531-538.

Chiang HC, Hodson AC. 1972. Population fluctuations of the European corn borer Ostrinia nubilalis at Waseca, Minnesota. Environmental Entomology 1:7-16.

Derridj S, Fiala V, Barry P, Robert P, Roessingh P, Staedler E. 1992. Role of nutrients found in the phylloplane, in the insect host-plant selection for oviposition. In: Menken SBJ, Visser JH, Harrewijn $\mathrm{P}$ (Eds.), The 8th International Symposium of Insect-Plant Relationships. pp. 139-140. Dordrecht: Kluwer Academic Press.

Despins JL, Roberts JE. 1986. Within-plant and within-field distribution of first-generation European corn borer (Lepidoptera: Pyralidae) egg masses on field corn in Virginia. Environmental Entomology 15:106-108.

Dunsong L, Zhang B, Huang S, Feng L. 2004. The occurrence and damages of insect pests on sweet corn in Guangdong Province. Acta Phytophylacica Sinica 004-1. Available at: http:// en.cnki.com.cn. [accessed 12 January 2012].

Dunsong L, Shao-hua H, Bao-xin Z, Yan-jun W, Hui-ling L. 2007. The seasonal occurrences of Ostrinia furnacalis and its egg parasitic wasps on sweet corn in Pearl River Delta Region. Acta Phytophylacica Sinica 2007-02. Available at: http://en.cnki.com.cn. [accessed 12 January 2012].
Elliot JM. 1977. Statistical Analysis of Samples of Benthic Invertebrates, $2^{\text {nd }}$ Edition. Cumbria: Freshwater Biological Association. Scientific Publication No. 25.

Hunt TE, Higley LG, Witkowski JF, Young LJ, \& Hellmich RL. 2011. Dispersal of adult european corn borer (Lepidoptera: Crambidae) within and proximal to irrigated and non-irrigated corn. Journal of Economic Entomology 94:13691377. doi: http://dx.doi.org/10.1603/0022-049394.6.1369.

Khaing O, Praparat H, Surachrat J, Ngarmchuen R, Arunee W. 2002. Spatial dispersion and optimum sample size for cotton bollworm, Helicoverpa armigera (Hübner) (Lepidoptera: Noctuidae) larvae on cCotton. Kasetsart Journal (Natural Science) 36:235-241.

Kuno E. 1991. Sampling and analysis of insect populations. Annual Review of Entomology 36:285-304. doi: http://dx.doi.org/10.1146/ annurev.en.36.010191.001441.

Lee DA. 1988. Moth density and oviposition patterns of the European corn borer, Ostrinia nubilalis (Lepidoptera: Pyralidae) in Alberta. Environmental Entomology 17:220-224.

Nafus DM, Schreiner IH. 1987. Location of Ostrinia furnacalis (Lepidoptera: Pyralidae) eggs and larvae on sweet corn in relation to plant growth stage. Journal of Economic Entomology 80:411416.

Nonci N, Tandiabang J, Baco D. 1996. Kehilangan Hasil oleh Penggerek Jagung (Ostrinia furnacalis) pada Berbagai Stadia Tanaman Jagung. Hasil Penelitian Hama/Penyakit 1995/1996. Maros: Balai Penelitian Tanaman Serealia.

Qureshi JA, Buschman LL, Throne JE, Ramaswamy SB. 2005. Adult dispersal of Ostrinia nubilalis Hubner (Lepidoptera: Crambidae) and its implications for resistance management in Btmaize. Journal of Applied Entomology 129: 281-292. doi: http://dx.doi.org/10.1111/j.14390418.2005.00966.x

Rosenberg MS, Anderson CD. 2011. PASSaGE: Pattern analysis, spatial satistics and geographic exegesis. Version 2. Methods in Ecology \& Evolution 2:229-232. doi: http://dx.doi. org/10.1111/j.2041-210X.2010.00081.x.

Sorenson CE, Kennedy GG, Vanduyn JW, Bradley JR. 1993. Distribution of second generation European corn borer, Ostrinia nubilalis, egg masses in field corn and relationship to subsequent tunnelling damage. Entomologia 
Experimentalis et Applicata 68:15-23. doi: Wright RJ, Devries TA, Young LJ, Jarvi KJ, http://dx.doi.org/10.1111/j.1570-7458.1993. Seymour RC. 2002. Geostatistical analysis of tb01684.x.

Southwood TRE, Henderson PA. 2000. Ecological Methods. 3rd ed. 575p. UK: Blackwell Science.

Spanglera SM, Calvin DD. 2001. Vertical distribution of european corn borer (Lepidoptera: Crambidae) egg masses on sweet corn. Environmental the small-scale distribution of european corn borer (Lepidoptera: Crambidae) larvae and damage in whorl stage corn. Available at: http:// digitalcommons.unl.edu. [accessed 24 February 2012].

Entomology 30:274-279. doi: http://dx.doi. org/10.1603/0046-225X-30.2.274. 